\title{
Ryegrass endophyte-related heat stress in cattle
}

\author{
H.S. EASTON' ${ }^{\prime}$, G.A. LANE', B.A. TAPPER', R.G. KEOGH', B.M. COOPER ${ }^{2}$, \\ M. BLACKWELL ${ }^{3}$, M. ANDERSON ${ }^{4}$ and L.R. FLETCHER ${ }^{5}$ \\ 1 AgResearch, $P B$ 11008, Palmerston North \\ 2 AgResearch, PO Box 23, Kerikeri \\ ${ }^{3}$ Livestock Improvement, 17 Melwood Drive, Warkworth \\ ${ }^{4}$ Kaipara Veterinary Services, 45 Commercial Road, Helensville \\ ${ }^{5}$ AgResearch, PO Box 60, Lincoln
}

\begin{abstract}
Heat stress in Northland cattle has been shown to be similar to tall fescue toxicosis as described in south-east USA, but incidence has not been correlated with the presence of tall fescue on farms. Tall fescue toxicosis results from grazing endophyte-infected tall fescue, and is caused by the alkaloid ergovaline. Cases are described of cattle suffering typical symptoms of ergovaline poisoning, though they had negligible access to tall fescue. Pasture surveys have shown ergovaline levels in ryegrass pastures to often be sufficient to cause toxicosis. Ambient temperatures interact with ingestion of toxin to cause heat stress. It is suggested that usual weather conditions in New Zealand temper the negative effects of the toxin. Higher temperatures increase the levels of ergovaline in pasture, and increase the sensitivity of livestock to it. Heat stress in North Island cattle probably usually results from the interaction of particular environmental conditions with the grazing of perennial ryegrass.
\end{abstract}

K eywords: endophyte, ergovaline, fescue toxicosis, heat stress, Loliumperenne

\section{Introduction}

Cases of heat stress in cattle in Northland, Bay of Plenty and occasionally elsewhere have been reported (Anon. 1977, 1978; Sutherland 1984; Brookbanks et al. 1985). Symptoms included high rectal temperatures, high respiration rate, panting, drooling of clear mucus from the mouth and nose, extrusion of the tongue and search for shade and cool. A loss of condition was reported, with rough coats often coated with mud or faeces (Anon. 1977). Production could drop dramatically, affected animals could take several weeks to recover and 6-30\% of animals in a herd could be affected (Sutherland 1984). Inadequate sodium (or excessive potassium), tall fescue and ticks were suggested as possible causes (Anon. 1977). However, none of these factors was consistently associated with the problem, and the suggestion was made that Friesian cattle were simply intolerant of high ambient temperatures (Anon. 1978). Sutherland (1984) pointed out that feverish body temperatures occurred "against a background of environmental conditions which would not be expected to overwhelm the thermoregulatory system", and noted the similarity to tall fescue "summer syndrome" of cattle grazing tall fescue reported in the USA. Brookbanks et al. (1985) reported that the disorder was prevalent north of Auckland, 3-80\% of animals in affected herds showing heat stress. Production losses up to 50\% (herd basis) were reported. Tall fescue was present on all properties but in some was restricted to a little in farm races. Kearns (1986) surveyed 64 dairy herds and was unable to correlate heat stress incidence or severity with any factor except breed. Tall fescue was present on all properties but its abundance and availability were not related to the degree of heat stress in the herd. Reports of fescue-related heat stress are usually from the north of New Zealand where sustained periods of warm temperatures are encountered, but the problem can occur elsewhere. Three bullocks developed very high temperatures, salivated heavily, extended their tongues and eventually died after grazing wild tall fescue in Manawatu (P.R. Wiseman, H.S. Easton, unpublished).

"Summer syndrome" in cattle grazing tall fescue has been intensively researched in southern USA since 1950 (Pratt \& Haynes 19501, and has been shown to be caused by the infection of tall fescue with the endophyte fungus Acremonium coenophialum (Hoveland et al. 1980; Hoveland 1993). The endophyte produces a number of chemical compounds, and the principal toxic agents are the ergopeptine alkaloids, notably ergovaline (Gamer et al. 1993). Clinical symptoms of fescue toxicosis were observed in animals grazing endophyteinfected tall fescue containing under $0.2 \mathrm{ppm}$ (parts per million) ergovaline, and in one experiment physiological effects were recorded when the diet contained only 0.05 ppm ergovaline. Tall fescue seed sold for pasture in New Zealand is free of endophyte.

A related endophyte, Acremonium lolii, infects most New Zealand pastures of perennial ryegrass and is the 
cause of ryegrass staggers (Fletcher \& Harvey 1981; Fletcher et al. 1990). The ryegrass-endophyte association produces a large number of alkaloid chemicals, notably lolitrem B (causing ryegrass staggers, Gallagher et al. 1984) and ergopeptine alkaloids including ergovaline (Rowan et al. 1990; Tapper 1993). On a trial in Canterbury, heat stress of lambs grazing endophyteinfected ryegrass was observed on the plots, and measured after animals were transferred to a heat chamber indoors (Fletcher 1993).

\section{Survey of $\mathrm{New}$ Zealand ryegrass pastures}

In summer-autumn 1992-93, samples were taken from perennial ryegrass-based pastures on farms in several regions of New Zealand. Samples were taken by a number of different people, and while instructions were given to cut close to the ground at 20 or more points at random through each paddock, some variation in practice probably occurred. Samples were taken in December, January and February-March. The results presented are from old ryegrass pastures and from pastures sown to readily available seed lines. They therefore reflect the typical situation of New Zealand perennial ryegrassbased pastures. Among the farms sampled in Northland were properties where heat stress in dairy herds had been reported.

Samples were taken in summer 1992-93 from a number of experiments in Canterbury, Manawatu, Hawke's Bay and Taranaki.

Samples were also taken in summer 1993-94, in Northland. Finally, samples were taken in April 1995 from farms in Waikato and near Dannevirke, where heat stress was reported in dairy cattle.

Samples were dissected to separate ryegrass from clover and other plant species, and the ryegrass fraction was frozen, freeze dried, ground and assayed for ergovaline by the method described by Barker et al. (1993). Determinations of ergovaline and its isomer ergovalinine were added to give the concentrations reported.

Figure 1 shows the evolution of mean ergovaline levels for all samples through summer-autumn 1992 93, and Figure 2 shows the distribution of all values in this period. These results have been summarised by Easton et al. (1993).

Elevated ergovaline concentrations in flowering stems and seed-heads account for an early peak for whole pasture samples in December (Figure 1). Beyond this period there is a steady increase to a second peak in late summer. Again, this peak is influenced by the high proportion of basal leaf sheath, high in ergovaline (Davies et al. 1993), in the low pasture profile associated with restricted pasture growth. Independently of
Figure 1 Levels of ergovaline (2-weekly mean and range) in 48 samples of endophyte-infected perennial ryegrass herbage from throughout New Zealand, SeptemberMay 1992-93. Points without a range bar indicate a single sample in a fortnight.

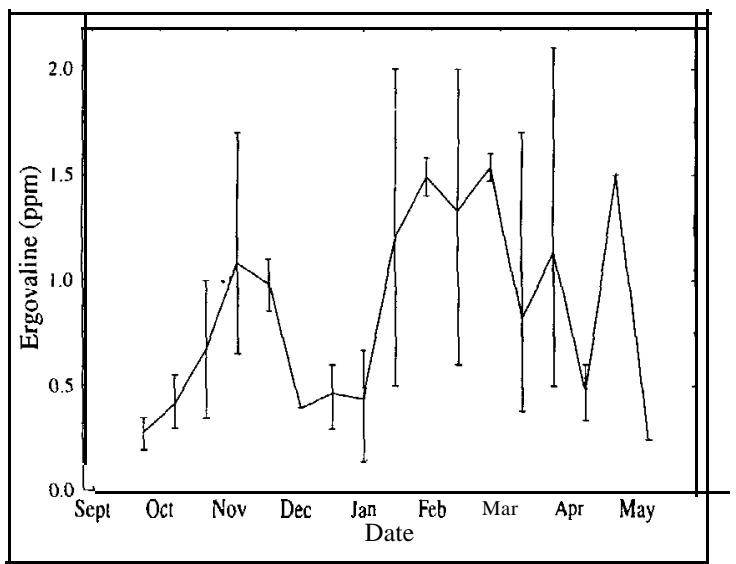

Figure 2 Distribution of ergovaline levels in 48 samples of endophyte-infected perennial ryegrass herbage from throughout New Zealand, September-May 1992-93.

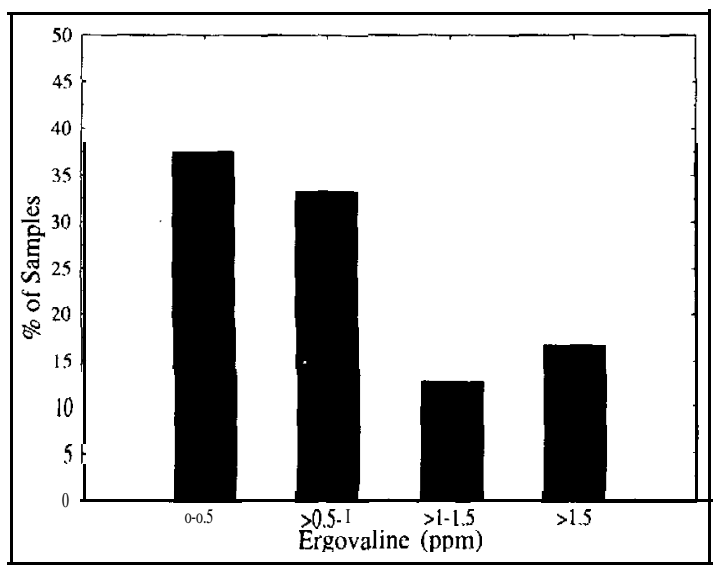

changing pasture profile, ergovaline levels are sometimes raised by water stress and increased ambient temperatures (Barker et al. 1993; Eerens 1996). Repeated sampling of a trial in Victoria, Australia, gave a similar trend in ergovaline levels through the summer and autumn (Woodburn et al. 1993).

The results do not indicate major differences between ergovaline levels in different regions of New Zealand. A more extensive data set for Grasslands Pacific ryegrass with 'Endosafe' also showed no consistent differences between regions (H.S. Easton, G.A. Lane, unpublished). 
Moderately high ergovaline content has been found in both old pastures and pasture sown to modern cultivars. Table 1 gives figures for samples taken from two Northland farms in January 1993. Nearly $50 \%$ of samples taken from old Waikato pastures in autumn 1992-93 had ergovaline levels higher than $0.5 \mathrm{ppm}$ (Figure 3). More than $15 \%$ had levels above $1.0 \mathrm{ppm}$. Levels of 1.6 and $1.9 \mathrm{ppm}$ (each a mean of four plots) were recorded on two modern cultivars at the Poukawa research station (Hawke's Bay) in January 1993, and levels above $1.0 \mathrm{ppm}$ were recorded on recently sown pastures on Waikato farms in February 1993.

Table 1 Ergovaline ppm in herbage samples from farms reporting heat stress in cattle.

\begin{tabular}{lll}
\hline Origin of sample & ppm & ergovaline \\
\hline Northland, Jan 93, Farm A, old pasture & 1.2 \\
Northland, Jan 93, Farm A, sown cultivar & 0.9 \\
Northland, Jan 93, Farm B, old pasture & 1.8 \\
Northland, Jan 93, Farm B, sown cultivar & 0.6 \\
Dannevirke, April 1995 & 1.0 \\
Waikato, April 1995, Farm A & 0.4 \\
Waikato, April 1995, Farm B & 0.1 \\
Waikato. April 1995, Farm C & 0.5
\end{tabular}

Figure 3 Distribution of ergovaline levels in 23 samples of endophyte-infected perennial ryegrass herbage from Waikato, April 1993.

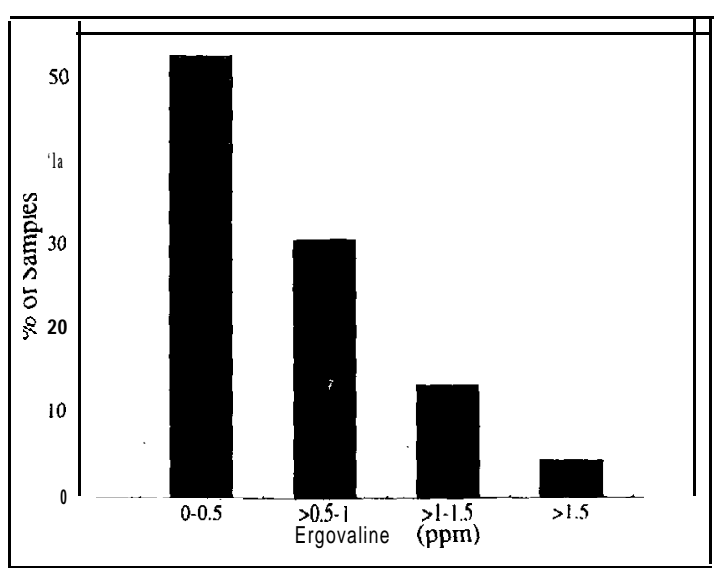

Figure 4 summarises results from 39 sites on 18 farms in Northland for January to April 1995. While the mean did not vary greatly through the season, the percentage of pastures with ergovaline levels above $1.0 \mathrm{ppm}$ was zero in March but above 30\% in February and between 15 and 20\% in January and April. Ergovaline levels in pastures in autumn vary greatly with local and seasonal conditions. In seasons that combine adequate soil moisture with warm temperatures and high levels of mineralised (or fertiliser) nitrogen (Lyons et al. 1986), the biological activity of the endophyte remains high and this is reflected in high ergovaline levels.

From all the above results, ergovaline levels between 0.5 and $1.0 \mathrm{ppm}$ are clearly commonplace in New Zealand ryegrass pastures in summer and autumn, and in some pastures levels are above $1.5 \mathrm{ppm}$.

Figure 4 Distribution of ergovaline levels in samples of endophyte-infected perennial ryegrass herbage from Northland, January-April 1994.

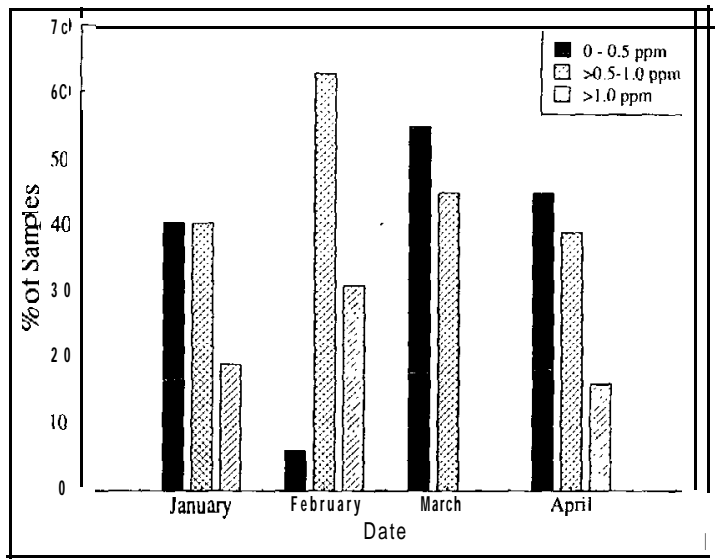

\section{Hyperthermia in dairy herds}

Between January and April 1993, the authors' attention was drawn to herds in Northland suffering from heat stress. Production had fallen, animals had lost their appetite and were visibly stressed, drooling and in some cases panting. The symptoms conformed to those described for tall fescue toxicosis "summer syndrome" in USA literature, and to earlier New Zealand reports (Anon. 1977; Sutherland 1984; Brookbanks et al. 1985). However, the amount of tall fescue herbage available to these herds was negligible. Likewise, in April 1995, severe heat stress was observed in several herds in Waikato, with losses in production and again negligible tall fescue herbage available. Similar observations were made in the Dannevirke area in southern Hawke's Bay. Herbage samples were taken from several paddocks on farms where heat stress was reported, within a few days of the reports being received, and while the symptoms were still evident. Ergovaline levels in herbage from farms where heat stress was reported are given in Table 1.

Ergovaline levels in samples from the affected Waikato farms in April 1995 were not unduly high, so these incidences remain inconclusive. In the other cases, 
ergovaline levels were sufficient to cause the symptoms usually ascribed to fescue toxicosis.

\section{Conclusions}

Despite differences in laboratory procedure, possibly leading to differences in absolute values, ergovaline levels in New Zealand ryegrass pastures in summer and autumn clearly often approach the range shown by tall fescue research to cause the elevated body temperatures and other symptoms associated with fescue toxicosis.

In many circumstances the feed actually ingested by cattle may be less toxic than indicated by analysis. Usually pastures are mixtures containing white clover, usually more abundant in summer months, so that the ergovaline in the ryegrass is diluted. Ergovaline concentrations are highest in the flowering stem and seed-head, and in the basal sheath of the plant (Keogh \& Tapper 1993). Samples taken for analysis were cut close to the ground, and cattle frequently graze above the layers in the pasture profile where the highest levels of ergovaline are found. However, this is not always so. On the other hand, random sampling is likely to underestimate the contribution to diet of urine patches (Keogh 1973), and ergovaline levels in these high nitrogen areas may be higher than elsewhere in the pasture (Lyons et al. 1986).

It will therefore not be unusual for cattle grazing endophyte-infected ryegrass in northern New Zealand to ingest herbage containing over $1 \mathrm{ppm}$ ergovaline, and sometimes over $1.5 \mathrm{ppm}$. These levels are much lower than those common in roadside tall fescue in New Zealand, but they approach the range of endophyteinfected tall fescue cultivars used in USA. The figures in Table 1, taken from properties where heat stress had been recently observed, are not unusual in New Zealand pastures. The relatively infrequent incidence of clinical heat stress in New Zealand cattle grazing perennial ryegrass must be ascribed to usually short-term exposure to elevated levels, and to the generally less heat stressinducing ambient conditions than those of south-east USA. There have not been reports of heat stress from Canterbury farms, although day-time temperatures there can be high. The lower night temperatures than those of northern North Island, allowing animals to recover, may account for this.

We conclude that ergovaline levels in perennial ryegrass pastures are sufficient to cause fescue toxicosis symptoms in livestock if ambient conditions aresuitable, and that for many reported cases of bovine ideopathic hyperthermia, endophyte-infected perennial ryegrass pastures are a more likely explanation than the very small amounts of volunteer tall fescue available to animals.

\section{REFERENCES}

Anonymous. 1977. Ideopathic bovine hyperthermia. Surveillance 4:4: 6-7.

Anonymous. 1978. Ideopathic bovine hyperthermia. Surveillance 5:1: 1 1-12.

Barker, D.J.; Davies, E.; Lane, G.A.; Latch, G.C.M.; Nott, H.M.; Tapper, B.A. 1993. Effect of water deficit and alkaloid concentrations in perennial ryegrass endophyte associations. Proceedings second international symposium on Acremonium grass interactions Ed. D.E. Hume, G.C.M. Latch \& H.S. Easton. AgResearch.. pp 67-71.

Brookbanks, E.O.; Bell, K.C.; Fraser, D.; Kearns, M.P.; Sutherland, R.J. 1985. Hyperthermia in cattle associated with tall fescue (Festuca arundinacea). NZ veterinary journal 33: 57-58.

Davies, E.; Lane, G.A.; Latch, G.C.M.; Tapper, B.A.: Garthwaite, I.; Towers, N.R.; Fletcher, L.R.; Pownell, D.B. 1993. Alkaloid concentrations in field-grown synthetic perennial ryegrass endophyte associations. Proceedings second international symposium on Acremonium/grass interactions. Ed. D.E. Hume, G.C.M. Latch \& H.S. Easton. AgResearch. pp 72-76.

Easton, H.S.; Lane, G.A.; Tapper, B.A. 1993. Ergovaline in endophyte-infected ryegrass pastures. Proceedings of a symposium on "Mycotoxicoses of Grassland Farming”, Ruakura, September 1993; Abstract in NZ veterinary journal 41: 214.

Eerens, J.P.J. 1996. Ryegrass endophyte in a cool moist environment. PhD thesis, Lincoln University.

Fletcher, L.R. 1993. Heat stress in lambs grazing ryegrass with different endophytes. Proceedings second international symposium on Acremonium/grass interactions. Ed. D.E. Hume, G.C.M. Latch \& H.S. Easton. AgResearch. pp 114-1 18.

Fletcher, L.R.; Harvey, I.C. 1981. An association of a Lolium endophyte with ryegrass staggers. NZ veterinary journal 29: 185-186.

Fletcher, L.R.: Hoglund, J.H.; Sutherland, B.L. 1990. The impact of Acremonium endophytes in New Zealand, past, present and future. Proceedings $\mathrm{NZ}$ Grassland Association 52: 227-235.

Gallagher, R.T.; Hawkes, A.G; Steyn, P.S.; Vlegaar, R. 1984. Tremorgenic neurotoxins from perennial ryegrass causing ryegrass staggers disorder of livestock: structure and elucidation of lolitrem B. Journal Chemical Society, chemical communications (London): 614-616.

Garner, G.B.; Rottinghaus, G.E.; Cornell, C.N.: Testereci, H. 1993. Chemistry of compounds associated with endophyte/grass interaction: ergovaline- and ergopeptine-related alkaloids. In: 
Acremonium/grass Interactions. Ed. R. Joost \& S. Quisenberry. Elsevier. pp 65-80.

Hoveland, C.S. 1993. Importance and economic significance of the Acremonium endophytes to performance of animals and grass plant. In: Acremonium/grass Interactions Ed. R. Joost \& S. Quisenberry. Elsevier. pp 3-12.

Hoveland, C.S.; Haaland, R.L.; King, C.C.; Anthony, W.B.; Clark, E.M.; McGuire, J.A.; Smith, L.A.; Grimes, H.W.; Holliman, J.L. 1980. Association of Epichloe typhina fungus and steer performance on tall fescue pasture. Agronomy journal 72: 10641065.

Kearns, M.P. 1986. Tall fescue toxicity: an investigation of idiopathic bovine hyperthermia (IBH) in the North Auckland peninsula. Proceedings NZ Grassland Association 47: 183-186.

Keogh, R.G. 1973. Herbage growth and the grazing pattern of sheep set-stocked on a ryegrass-dominant, staggers prone pasture during summer. NZ journal of experimental agriculture I: 1-4.

Keogh, R.G.; Tapper, B.A. 1993. Acremonium lolii, lolitrem B and peramine concentrations within vegetative tillers of perennial ryegrass. Proceedings second international symposium on Acremonium/ grass interactions: Ed. D.E. Hume, G.C.M. Latch \& H.S. Easton. AgResearch. pp 81-84.
Lyons, P.C.; Plattner, R.D.; Bacon, C.W. 1986 Occurrence of peptine and clavine ergot alkaloids in tall fescue. Science 232: 487-489.

Pratt, A.D.; Haynes, J.L. 1950. Herd performance on Kentucky 31 fescue. Ohio farm home research 35: $10-11$.

Rowan, D.D.; Tapper, B.A.; Sergejew, N.L.; Latch, G.C.M. 1990. Ergopeptine alkaloids in endophyteinfected ryegrasses and fescues in New Zealand. Proceedings international symposium on Acremonium/grass interactions Ed. R. Joost \& S. Quisenberry. Louisiana Agricultural Experimental Station. pp 97-99.

Sutherland, R.J. 1984. Ideopathic bovine hyperthermia. Surveillance 11:3: 16-1 7.

Tapper, B.A. 1993. A New Zealand perspective on endophyte metabolites. Proceedings second international symposium on Acremonium/grass interactions: Plenarypapers. $\boldsymbol{F} d$. D.E. Hume, G.C.M. Latch \& H.S. Easton. AgResearch. pp 89-93.

Woodburn, O.J.; Walsh, J.R.; Foot, J.Z.; Heazlewood, P.G. 1993. Seasonal ergovaline concentrations in perennial ryegrass cultivars of differing endophyte status. Proceedingssecond internationalsymposium on Acremonium/grass interactions. Ed. D.E. Hume, G.C.M. Latch \& H.S. Easton. AgResearch. pp 100102. 